\title{
Studi Isu Lingkungan di Kecamatan Coblong, Kota Bandung
}

\author{
Gede H. Cahyana
}

\begin{abstract}
Abstrak
Telah dilaksanakan studi di Kecamatan Coblong Kota Bandung. Hasil identifikasinya berupa sejumlah isu lingkungan, baik skala kecil maupun skala besar. Di antara isu yang diperoleh ialah masalah sanitasi yang mencakup penyediaan air bersih, penyaluran air limbah, drainase, polusi udara dan bising, serta persampahan. Agar dampak masalah lingkungan itu bisa dikurangi, perlu diadakan penyuluhan atau pendidikan masyarakat, terutama yang menyangkut air limbah dan sampah. Sesegera mungkin diberikan pemahaman bahwa kesehatan dapat ditingkatkan dengan peduli lingkungan, tidak membuang air limbah ke selokan tetapi minimal ke tangki septik dan tidak membuang sampah ke sembarang tempat. Sampah sebaiknya dipilah menjadi organik dan anorganik. Yang organik ditanam di halaman rumah, yang anorganik diberikan kepada pemulung. Di sektor polusi udara hendaklah dibatasi jumlah kendaraan bermotor dengan membuat transportasi massal. Agar masyarakat Kota Bandung mau menggunakannya, hendaklah dirawat dengan baik dan nyaman. Keamanan pun penting di kendaraan massal ini. Makin aman dan relatif murah, makin banyak yang akan menggunakannya.
\end{abstract}

Kata kunci: identifikasi, Coblong, polusi, organik, anorganik.

\section{Latar Belakang}

Seiring dengan perkembangan kota yang meliputi perluasan wilayah, pertambahan jumlah penduduk, peningkatan kualitas ekonomi, sosial, budaya kian banyak juga masalah lingkungan dan ekologi yang tejadi. Tidak hanya di kota-kota besar tetapi juga di kota-kota sedang. Pertumbuhan Kota Bandung sebagai kota pendidikan dan wisata, khususnya wisata belanja akhir pekan dan libur panjang, apalagi disertai dengan kebijakan libur atau cuti bersama, membuat kota di cekungan raya ini kian semarak oleh pendatang musiman.

Akibatnya, masalah lingkungan hadir sebagai konsekuensi logis. Tak hanya di bidang penyediaan air minum dan penyaluran air limbah, juga mencakup drainase, sampah, dan sanitasi di tempat umum, baik berupa fasilitas sosial (fasos) maupun umum (fasum). Seberapa besar dampak perkembangan kota terhadap lingkungan Kota Bandung bergantung pada tingkat kedatangan wisatawan dan pengunjung musiman itu, selain tentu saja dipengaruhi oleh penduduk setempat. 


\section{Maksud dan Tujuan}

Kegiatan studi ini dimaksudkan untuk mencari dan menganalisis masalah atau isu lingkungan di Kota Bandung. Lebih khusus lagi ialah mendeteksi masalah lingkungan di tingkat kelurahan terutama yang berkaitan dengan aspek sanitasi masyarakat.

Agar maksud di atas tercapai, dibuatlah langkah per langkah untuk membantu studi ini. Beberapa langkah yang dijadikan tujuan studi ialah (1) mendata masalah lingkungan di Kota Bandung, (2) menganalisis isu lingkungan dan memberikan alternatif solusinya, serta (3) memetakan isu lingkungannya.

\section{Metodologi}

Seperti umumnya penelitian, kegiatan studi pustaka diperlukan untuk memberikan latar belakang awal tentang masalah yang akan dipelajari. Juga untuk melihat fenomena objek studi dan menelaah hasil studi sebelumnya yang berkaitan dengan kondisi daerah studi. Berbagai sumber pustaka digunakan untuk membandingkan atau dijadikan rujukan seperti buku, kajian ilmiah populer di koran, berita di media massa, dan prosiding seminar. Tahap studi pustaka ini dilaksanakan mulai persiapan studi, selama studi, sampai akhir masa studi.

Agar tujuan studi tercapai, dibuatlah rumusan studi untuk menetapkan data yang akan dicari (diambil) dan cara mengumpulkannya. Pada tahap ini ditetapkan bahwa yang perlu diambil adalah data kondisi air baku, air bersih, air limbah, sampah, transportasi, polusi udara, dan kebisingan lingkungan. Artinya, materi studi ini banyak dititikberatkan pada sanitasi masyarakat. Sudut pandang lingkungan dari sisi biologi tidak terlampau diperhatikan tetapi lebih diarahkan pada aspek interaksi manusia dan lingkungannya yang dikenal dengan istilah ekologi.

\section{Karakteristik Daerah Studi}

Secara geografis, Kota Bandung berada di cekungan raya yang dikitari pegunungan. Seperti kabupaten dan kota lainnya di cekungan ini, Bandung pun menghadapi masalah lingkungan seperti krisis sumber daya air, baik untuk air minum, industri, komersial, peternakan, pertanian, dan wisata. Juga masalah dalam pertumbuhan penduduk akibat kelahiran dan urbanisasi, ledakan jumlah pengguna jalan raya dan kurang optimal dalam penataan ruang, pelokasian tempat-tempat bisnis, pasar modern, pasar tradisional, PKL, dan penataan permukiman kumuh (slum area).

Tak hanya itu, masalah terbesar kota yang pernah berjuluk Bunganya Kota-kota Pegunungan di Nusantara (Der bloem der indische bergsteiden) ini memiliki daerah padat dan kumuh seperti di Cicadas dan di bantaran Sungai Cikapundung. Buruknya fasilitas sanitasi kota Priangan ini diindikasikan oleh cakupan distribusi air bersihnya yang masih rendah. Padahal salah satu penentu status kota ialah tingkat layanan air bersihnya, apalagi sekarang ada dasawarsa air bersih yang terangkum dalam program Millenium Development Goals (MDGs, 2015). Begitu pun masalah sampah, sistem 
koleksinya, transportasinya serta tempat penampungan sementaranya yang tidak terurus di sudut-sudut jalan.

Hal senada juga terjadi pada pipa air limbah (riulnya) yang dibangun oleh BUDP (Bandung Urban Development Project) pada era 1980-an. Peningkatan layanan penyaluran air limbah di sekitar pipa induk dan pipa cabang diakui masih belum meluas. Dampaknya, banyak ruas pipanya tetap "kering" karena tak ada air limbah yang masuk tetapi justru terisi dan tersumbat sampah. Ironisnya, sejak September 2007 s.d Februari 2008 dipasang lagi pipa riul besar berdiameter $800 \mathrm{~mm}$ di jalan Bypass (SoekarnoHatta). Bisa dikatakan, riul itu telah berfungsi sebagai bioreaktor anaerob sehingga menimbulkan bau busuk akibat rilisan gas $\mathrm{H}_{2} \mathrm{~S}, \mathrm{NH}_{3}$, dan bau dari asam-asam volatil. Yang juga menjadi masalah ialah manhole-manholenya (lubang inspeksi) tidak tertutup sempurna, ada yang hilang penutupnya, atau dijadikan tempat pembuangan air limbah oleh sopir mobil tangki tinja. Yang paling parah ialah ketika masyarakat pun membuang sampah ke dalam riul lewat manhole itu.

\section{Geohidrologi}

Dengan elevasi di atas $650 \mathrm{~m}$ dari permukaan laut, dikelilingi gunung dan tinggi curah hujannya, secara teoretis cekungan Bandung tidak akan bermasalah dalam air bersih. Kebutuhan domestik dan komersialnya tercukupi oleh air tanah (dangkal \& dalam) dan air permukaan. Merujuk pada satu studi, potensi air tanah di cekungan Bandung sekitar 1.400 liter/detik. Namun debit pemompaan air tanahnya sudah kritis, antara 620 s.d 1.700 1/d. Padahal air hujan yang jatuh di gunung perlu puluhan tahun untuk mengisi cekungan Bandung karena rendah kecepatannya, kurang dari $2 \mathrm{~m} /$ tahun. Itu pun kalau air hujannya tidak langsung melimpas ke sungai menuju laut. Jika daerah tangsap (tangkap-resapnya) menyempit, selain banjir juga bisa terjadi penurunan paras air tanah. Ini sudah terjadi di beberapa tempat seperti Batujajar, Buahbatu, Ujung Berung dengan variasi penurunan antara 0,5 dan $12 \mathrm{~m} /$ tahun.

Mengingat kejadian pencekungan paras air tanah itu terjadi di banyak tempat, maka perlu penatalaksanaan dan diversifikasi sumber-sumber air. Perlu ada studi untuk mengkaji potensi air yang bisa dimanfaatkan sekecil apapun kapasitasnya atau seburuk apapun kualitasnya. Biasanya pada tahap perencanaan, asumsi yang diambil untuk air bersih orang kota agar bisa hidup higienis ialah 150 - 200 liter/orang/hari (disingkat loh). Adapun orang desa dan kota kecil antara 60 - 80 loh yang disuplai dari hidran umum dan sambungan rumah. Namun pembagian seperti itu sifatnya tidaklah mutlak atau harga mati karena proyeksi kebutuhan airnya sudah makin kompleks. Apalagi di Bandung ini lebih dari $60 \%$ kebutuhan air masyarakatnya diambil dari air tanah. Sisanya berasal dari PDAM.

Air permukaan, khususnya sungai besar dan kecil yang ada di Kota Bandung ini berjumlah 46 buah dengan panjang total $268 \mathrm{~km}$ serta 77 buah mata air yang saat ini berada dalam keadaan kritis. Kota Bandung tengah menghadapi kekeringan sekaligus penurunan muka air tanah. Dalam sepuluh tahun terakhir ini muka air tanah dangkalnya 
turun hingga 10 meter dan air tanah-dalamnya bahkan turun 80 meter. Akibatnya terjadilah ambles (land subsidence) di sejumlah tempat. Kondisi ini diperparah dengan kerusakan di Kawasan Bandung Utara (KBU) yang mencapai 70\%. Kawasan ini merupakan kawasan lindung dan daerah tangkap-resap air hujan bagi cekungan Bandung dengan potensi 0,25 x 1,2 milyar m3/tahun dan merupakan $60 \%$ dari sumber pasokan air tanah Kota Bandung serta merupakan infrastruktur alam yang menjaga cuaca di Kota Bandung.

Tentu saja, selain upaya implementasi kearifan lokal itu perlu juga dipelihara badanbadan air seperti sungai. Hendaklah program rehabilitasi sungai, misalnya Citarum Bergeutar, Cikapundung bersih (Gerakan Cikapundung Bersih) rutin dilaksanakan dalam bentuk aksi nyata sehingga masyarakat yakin program dan gerakan tersebut tidak sekadar isu tetapi betul-betul dilaksanakan. Patut diingat, tidak cukuplah memberikan perhatian pada satu dua sungai saja. Semua sungai, besar maupun kecil berhak dirawat seperti Cikapundung Kolot, Ciparungpung (anak S. Cipamokolan), Cikiley (anak S. Cidurian), Cidurian dan Citepus. Semua sungai itu punya fungsi setara sebagai sungai pematus atau drainase kota. Warga kota hendaklah diajari bahwa sungai bukanlah tempat pembuangan air limbah mentah dari rumah, warung, toko, restoran, hotel, dll. Air limbah itu harus diolah dulu, minimal dengan tangki septik, lebih bagus lagi dengan Zontech Water Treatment, sebuah paket inovasi instalasi pengolahan air limbah, baru kemudian dibuang ke sungai.

\section{Penyediaan Air Minum}

Sanitasi dan hidup higienis tak dapat dipisahkan dari penyediaan air bersih. Air dapat dikatakan sebagai senyawa terpenting bagi manusia setelah oksigen (udara). Secara epistemologi, air berderajat sakral, merupakan asal kehidupan. Materi dengan rumus molekul $\mathrm{H}_{2} \mathrm{O}$ ini dominan di tubuh manusia, mencapai 65\%. Di tubuh anak-anak malah mencapai 75\%. Kesakralannya tercermin pada istilah berikut: tirtha nirmala, tirtha kamandalu, amrta njiwani (Sansekerta), maaul hayat (Arab), nectar-ambrosia (Yunani), the elixir of life, the liquid of life (Inggris), air suci (Indonesia).

Lantaran besar manfaat dan pengaruh air pada hidup manusia, maka di sektor air bersih ini pemerintah Indonesia sudah memberikan peluang kepada setiap daerah untuk membuat BPAM (Badan Pengelola Air Minum) sebagai embrio PDAM. Masyarakat harus dibantu dan dimudahkan dalam mendapatkan air bersih. Sampai awal tahun 2008 ini, tak kurang dari 318 PDAM sudah dibentuk di sejumlah kota dan kabupaten. Ada indikasi jumlah ini akan bertambah karena pemekaran daerah terus terjadi. Di cekungan Bandung saja ada PDAM Kabupaten Bandung, Kota Cimahi, dan Kota Bandung. Juga akan ada PDAM Kabupaten Bandung Barat tak lama lagi, paling lambat akhir tahun 2008.

\section{Erosi dan Sedimentasi}

Faktanya, kondisi kualitas air Sungai Cikapundung terus memburuk. Pada musim hujan menjadi sangat keruh karena mengandung koloid dan suspended solid dari erosi di 
daerah Utara. Begitu pula sedimentasinya kian banyak dan mendangkalkan sungai pembelah Kota Bandung ini. Yang terbanyak pengaruhnya ialah adanya pembangunan di Punclut. Padahal gubernur menyatakan daerah itu sebagai kawasan lindung. Jauh sebelum ini sudah ada SK Gubernur No. 181/1992 yang peruntukannya sebagai bentang konservasi air. Dengan SK itu Punclut dizonasi menjadi tiga, yaitu zone hutan lindung, budi daya, dan permukiman. Permukiman ini tentu sangat terbatas dan berupa permukiman akrab berwawasan lingkungan.

Dalam kondisi krisis air di Bandung ini, Punclut dan KBU lainnya mesti dikonservasi karena sebagai penjaga potensi air tanah yang sekarang hanya tinggal $1.400 \mathrm{l} / \mathrm{d}$. Ini sudah kritis, seperti ditulis di atas, karena debit eksploitasinya antara $620-1.700 \mathrm{l} / \mathrm{d}$. Atau, dari 2.500-an unit sumur bor yang ada di Bandung ini, pemenuhan kebutuhan air warga Bandung mencapai 50 juta $\mathrm{m} 3 /$ tahun. Selain sebagai reservoir air, Punclut pun berperan dalam agenda lingkungan di Kota Bandung. Di antaranya ialah erosi, sedimentasi solid di sungai, sistem koleksi air kotor, sistem koleksi dan tempat pembuangan akhir sampah, polusi udara, zonasi pertanian, industri, permukiman, banjir dan drainase.

\section{Persampahan}

Sampah secara garis besar dapat digolongkan menjadi tiga, yaitu: sampah rumah tangga, sampah industri dan sampah berbahaya (B3). Sampah rumah tangga atau kota (municipal) berasal dari kegiatan dapur seperti sisa sayur, daging dan buah. Ini termasuk kelompok sampah mudah membusuk atau garbage. Sampah ini mudah diuraikan oleh bakteri sehingga disebut biodegradable dan sampah jenis ini bisa dijadikan pupuk. Selain itu ada juga sampah plastik, kain perca, kaleng dll yang disebut rubbish. Sampah ini ada yang mudah terbakar dan ada yang tidak bisa terbakar. Adapun sampah industri adalah semua sampah yang berasal dari kegiatan industri, termasuk rubbish, debu, dan limbah berbahaya. Sampah berbahaya ialah sampah yang berpotensi membahayakan manusia, hewan dan tumbuh-tumbuhan dengan sifat antara lain: korosif, reaktif, radioaktif, eksplosif, dll.

Kota Bandung, minimal sejak longsor TPA Leuwigajah pada 21 Februari 2005 sampai sekarang masih sulit atau kewalahan menangani masalah sampah. Dengan penduduk lebih dari 2,5 juta orang, bisa dibayangkan berapa ton atau volume total sampah yang dihasilkan per hari. Ada data yang menyatakan bahwa timbulan sampah di Bandung mencapai $5.000 \mathrm{~m} 3 /$ hari. Kalau berat jenis (BJ) sampah dianggap 0,25 maka rata-rata beratnya menjadi 1.250 ton per hari. Kalau diambil analogi dengan gajah yang beratnya 1,25 ton per ekor maka di Kota Bandung akan timbul gajah "sampah" sebanyak 1.000 "ekor" setiap hari dan akan menumpuk terus dari hari ke hari.

\section{Kecamatan Coblong}

Coblong adalah salah satu kecamatan di Kota Bandung yang terletak di bagian Utara. Kecamatan ini terdiri atas enam (6) kelurahan, yaitu:

1. Kelurahan Cipaganti 
2. Kelurahan Lebak Siliwangi

3. Kelurahan Lebak Gede

4. Kelurahan Sadang Serang

5. Kelurahan Sekeloa

6. Kelurahan Dago

Batas wilayah Kecamatan Coblong ialah:

Di sebelah Utara berbatasan dengan Kecamatan Cimenyan Kabupaten Bandung

Di sebelah Selatan berbatasan dengan Kecamatan Bandung Wetan

Di sebelah Barat berbatasan dengan Kecamatan Sukajadi dan Kecamatan Cidadap

Di sebelah Timur berbatasan dengan Kecamatan Cibeunying Kaler.

\section{Demografi Coblong}

Kecamatan Coblong dengan jumlah penduduk 104.708 orang terdiri atas 74 Rukun Warga (RW) dan 464 Rukun Tetangga (RT) dengan kepadatan penduduk 141 orang/ha. Luas wilayah Kecamatan Coblong sekitar 743,3 ha. Sebagian besar daerah Kecamatan Coblong terdiri atas permukiman dengan kegiatan ekonomi yang didominasi oleh jasa pendidikan, perdagangan dan perkantoran. Malah semua perguruan tinggi negeri yang "dianggap" bagus oleh masyarakat berada di kecamatan ini. Jasa perdagangan di bidang Factory Outlet pun banyak di sepanjang jalan Dago. Begitu juga perkantoran negeri dan swasta.

Kecamatan Coblong sebagai pusat pengembangan jasa yang utama di Kota Bandung memiliki misi sebagai berikut: (1). Meningkatkan penyelenggaraan pemerintahan dan pelayanan prima yang profesional, (2). Membangun perekonomian lokal yang dinamis sebagai penunjang pengembangan dan keberlanjutan sentra kota jasa. (3). Membangun kehidupan sosial yang harmonis dengan ditunjang partisipasi masyarakat yang terus meningkat. (4). Meningkatkan penataan lingkungan kecamatan terutama lingkungan permukiman secara berkelanjutan.

Dalam hal perdagangan, yang dijadikan ikon atau produk unggulan Kecamatan Coblong antara lain meubel, daur ulang kertas, kerajinan kertas, kerajinan kulit, miniatur alat musik tradisional, bingkai sound system. Selain itu, "jasa" wisata dan perdagangan kecil, khususnya PKL juga banyak seperti kebun binatang, THR Juanda, Taman Ganesha Salman ITB, dan Sasana Budaya Ganesha.

\section{Penyediaan Air Bersih}

Seperti umumnya kondisi di Kota Bandung, sumber air bersih menjadi masalah utama di kecamatan ini. Memang, kantor pusat PDAM berada di kecamatan ini tepatnya di jalan Badaksinga. Walau demikian, tidak semua daerah di kecamatan ini mendapatkan suplai dari instalasi Badaksinga. Justru mayoritas pelanggan PDAM di daerah ini mendapatkan pasokan air bersih dari instalasi yang bukan di Badaksinga. Ini dapat dimaklumi karena lokasi kantor dan instalasi PDAM tepat berada di batas Selatan Kecamatan Coblong seperti dapat dilihat pada peta. 
Sumber air yang diperoleh warga di Kecamatan Coblong memang dari PDAM juga tetapi kebanyakan dari instalasi Dago Pakar. Di bawah ini adalah tabel debit produksi PDAM. Tampak bahwa IPA Dago Pakar memperoleh air baku dari Cikapundung sebesar 600 1/d. Adapun instalasi Badaksinga mengolah air Cikapundung: 200 1/d.

Tabel 1. Debit produksi air bersih PDAM Kota Bandung.

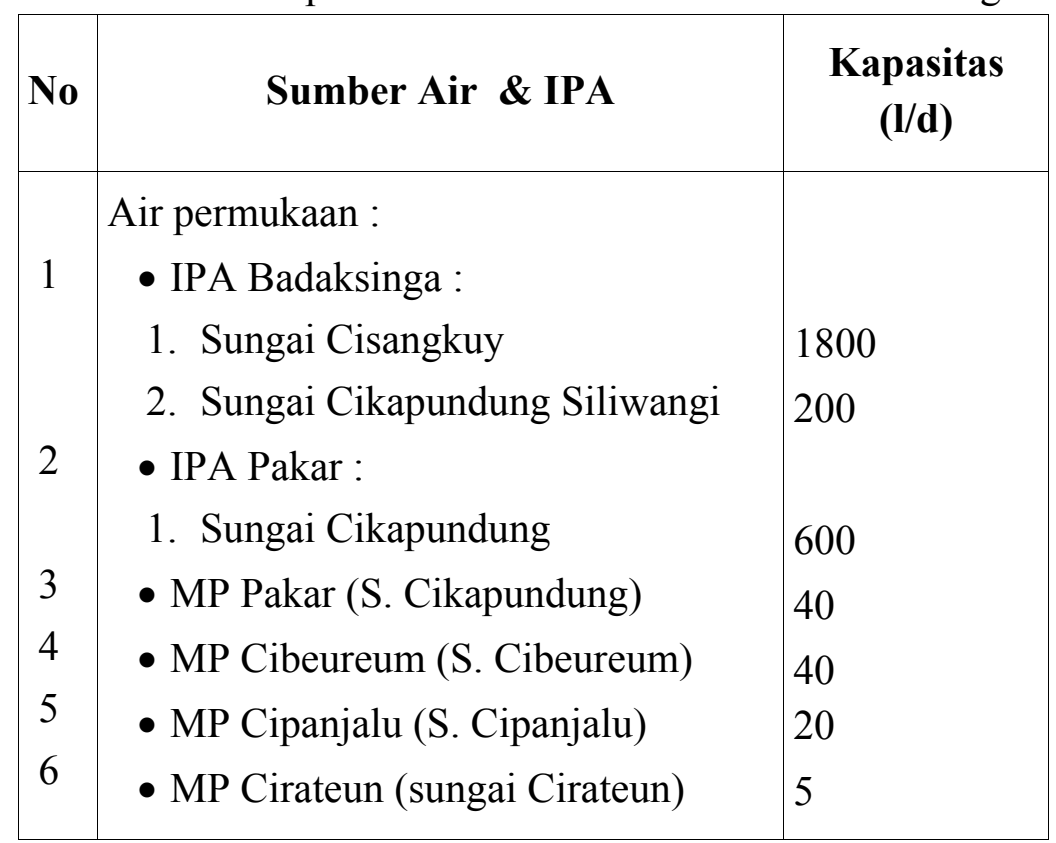

Sumber: Semiloka PDAM, 2007.

Selain dari PDAM, warga Kecamatan Coblong memperoleh air dari air tanah dangkal dan air tanah dalam. Ada juga yang memperoleh air dari mata air tanah dangkal karena ketika kemarau debitnya menyusut. Dengan cara sederhana warga membuat bak penampung lalu airnya dialirkan dengan selang dan pipa. Yang seperti ini perlu diberi bantuan agar warga bisa membaik kondisi sanitasinya.

\section{Penyaluran Air Limbah}

Air limbah yang dihasilkan oleh warga Kecamatan Coblong lebih banyak dibuang ke sistem setempat (on site). Ada sebagian yang sudah dialirkan ke pipa riul terutama yang berada di jalan besar. Namun masih banyak yang dibuang ke selokan atau sungai kecil di dekat rumahnya. Yang banyak terjadi, air limbah ini banyak dibuang ke Sungai Cikapundung. Sebagai contoh, warga di Kelurahan Cipaganti dan Lebak Siliwangi banyak yang mengalirkan air limbahnya ke sungai ini. Untung saja debit air sungai ini cukup besar sehingga terjadi pengenceran (dilusi) air limbah dan beban polutannya menurun.

\section{Drainase}

Kondisi drainase di Kecamatan Coblong masih belum bagus. Banyak yang ditutupi sampah, rumput, dan ada yang dindingnya rubuh. Di persimpangan jalan banyak saluran drainasenya yang tersumbat sampah sehingga pada saat hujan airnya naik ke badan 
jalan. Ini lama-lama dapat mengelupaskan aspal atau merusak jalan raya. Yang cukup bagus adalah di sepanjang jalan Dago, mulai dari terminal Dago sampai depan RS Borromeus.

Di daerah Sadang Serang juga drainase kurang bagus, termasuk yang di dekat terminalnya. Dari daerah ini menuju jalan Cikutra air di salurannya juga sering meluap dan kecepatan tinggi karena banyak daerah yang relatif menurun tajam. Di bagian pertemuan dua atau tiga saluran, pada saat hujan airnya muncrat ke atas dan meluber ke jalan raya. Ini terjadi karena dimensi saluran dan gorong-gorongnya terlalu kecil sehingga tidak cukup meloloskan air berdebit besar. Apalagi pada saat hujan sangat deras. Contoh foto saluran drainase yang tidak berfungsi optimal dapat dilihat pada gambar di bawah ini.

\section{Polusi Udara dan Kebisingan}

Transportasi, polusi udara dan kebisingan ternyata berkaitan. Dominasi kendaraan bermotor yang memacetkan jalan otomatis mengeluarkan asap jelaga dan gas pencemar. Pada saat yang sama terjadilah kebisingan mesin kendaraan. Tambah bising lagi ketika pengendaranya membunyikan klakson karena tidak sabar sehingga menambah ruwet suasana. Ini bisa disaksikan setiap hari, terutama pagi hari perapatan jalan. Ketika hujan lebih parah lagi karena jalan menjadi licin sehingga kendaraan pelan lajunya.

Daerah yang sering macet atau antrian kendaraannya panjang adalah daerah Simpang Dago, yaitu perapatan dengan jalan Dipati Ukur. Panjang antrian bisa sampai ke atas, ke dekat terminal Dago pada masa libur panjang dan ketika siang atau sore harinya terjadi hujan lebat.

\section{Sampah dan Limbah B3}

Sampah bukanlah musuh melainkan sumber daya. Artinya, sampah bisa dijadikan sumber pendapatan berupa uang kalau sampah itu dijual, dijadikan benda lain yang bernilai ekonomi atau diubah menjadi pupuk. Itu sebabnya, sampah hendaklah dijadikan sumber daya dan bukan sebagai sumber masalah. Dulu di Kelurahan Dago, tepatnya di daerah Cisitu ada yang namanya Kawaan Industri Sampah (KIS) dengan pelopor Prof. Hasan Purbo. Hanya saja, kawasan ini sudah lama tidak berfungsi lagi. Namun demikian, di sejumlah daerah ada upaya untuk memilah-milah sampah, ada yang dijadikan kompos. Tapi ada juga yang dibakar.

Sebaiknya sampah itu jangan dibakar. Yang terjadi sekarang adalah pembakaran sampah di dekat Sasana Budaya Ganesha ITB. Semua sampah yang ditimbulkan ITB dibawa ke tempat ini lalu dibakar dengan insinerator kecil. Sampah memang hilang tetapi seseungguhnya sampah itu berubah menjadi pencemar udara, baik berupa asap, jelaga maupun gas-gas lainnya. 


\section{Isu Utama Lingkungan}

Daerah yang dijadikan isu utama dalam studi ini adalah Kelurahan Cipaganti. Di sini terjadi kesulitan air bersih atau air bersihlah yang menjadi masalah utama. Ironisnya, daerah ini justru bertepian dengan sungai besar di Bandung, yaitu Cikapundung. Dengan kata lain, seharusnya daerah ini dapat memanfaatkan air ini untuk sumber air bersihnya, baik untuk makan, minum, mencuci, berkebun dll.

Sampai awal tahun 2008 ini, sumber air yang digunakan warga bisa dikelompokkan menjadi dua, yaitu bersifat pribadi dan komunal. Sumber air pribadi ini berupa (1) air tanah yang diperoleh dari sumur gali dan sumur pompa. Jelas sekali, air ini berasal dari resapan air S. Cikapundung. Yang kedua adalah air PDAM. Adapun sumber air komunal berasal dari: (1) mata air di seberang Sungai Cikapundung; (2) air buangan dari Sabuga (Sasana Budaya Genesha). Warga menyalurkan air ini menggunakan selang dan pipa PVC melintasi Sungai Cikapundung.

Berdasarkan keterangan warga, keterbatasan debit air dari sumber mata air di seberang Sungai Cikapundung membuat warga memilih menggunakan air buangan dari Sabuga karena debitnya besar. Air buangan Sabuga ini dimanfaatkan untuk mencuci dan mandi. Hanya saja, ada warga yang mengeluh karena kulitnya sering gatal-gatal setelah mandi menggunakan air limbah Sabuga itu. Ini mungkin disebabkan oleh kualitas airnya yang tidak memenuhi syarat kualitas air bersih atau terkontaminasi di bagian atasnya, sebelum dimanfaatkan warga. Air ini ada juga yang berasal dari buangan pengurasan kolam renang yang dialirkan melalui selokan di Sabuga dan dibuang ke Sungai Cikapundung.

\section{Kesimpulan}

Isu utama lingkungan di Kecamatan Coblong ialah masalah air bersih, penyaluran air limbah, drainase, polusi udara dan bising, serta persampahan. Agar masalah itu dapat dikurangi dampaknya perlu diadakan penyuluhan masyarakat, terutama yang menyangkut masalah air limbah dan sampah.

Di sektor polusi udara hendaklah dibatasi jumlah kendaraan bermotor yang ada di jalan atau dengan membuat transportasi massal. Agar masyarakat Kota Bandung mau menggunakannya maka hendaklah dirawat dengan baik dan nyaman. Keamanan pun penting di kendaraan massal ini. Makin aman dan relatif murah di kantong warga kebanyakan, makin banyak yang akan menggunakannya.

\section{Saran}

Normalkan selokan agar drainase dapat menampung limpasan air hujan. Perlu program pendidikan (pelatihan) masyarakat di bidang air limbah dan sampah. Perluasan daerah tangsap air hujan dengan membangun sumur atau bidang resapan di rumah atau di kantor pemerintah. Perluasan hutan kota dan kawasan terbuka hijau. Menata permukiman terutama yang di tepi selokan atau sungai agar tidak semrawut. Lalu yang terakhir, tegakkan hukum lingkungan terhadap siapa saja.* 


\section{Daftar Pustaka}

1. Anonim, (2007), Monograf Kecamatan Coblong, Kota Bandung.

2. Cahyana, G. H. (2004), PDAM Bangkrut? Awas Perang Air, Sahara Golden Press.

3. Purwasasmita, M. (2005), Orasi Ilmiah, Universitas Kebangsaan Bandung.

4. Semiloka PDAM Kota Bandung, (2007), Bandung.

5. Berbagai sumber di media massa cetak.

Hasil penelitian, dipublikasikan di Jurnal Sosioteknologi Terapan, Volume IX Bulan Februari-Juni 2008, hlm. 112-125. ISBN 978-979-17974-0-5 